New editorial associate, Dr. Panos D. Bardis of Toledo University, contributed this poem after a visit to South Africa.

\title{
THE PROTEA PEACE PARADE
}

(For J. Harrison)

"You cannot step twice into the same river."

Heraclitus, On Nature, 500 B.C.

"Time, in the passing of days, works change

for better or worse."

Pinda, Odes, Fifth Century B.C.

"There is in the pang of change

something more than the heart can

bear - - unhappiness remembering

happiness."

Euripides, Iphigenia in Tauris, 413 B.C.

"Change is the death of that which was

before."

Lucretius, De Rerum Natura, First

Century B.C.

I. The Sea-God's Flower

Brilliant bracts adorn your flaming,

Sparkling, dazzling diadem -.

Startling, silken bracts with hairiets

Like a golden maiden's down.

Fairest Queen of countless colours,

Sizes, shapes, and wondrous forms,

You have taken your sweet nectar

From a high Olympian peak.

Honeyflower, Honeysuckle,

Aphrodite's Hydromel,

So prolific and melliferous

Listen to the passing bell,

Listen to the pagan paeans

And the happy hymns and songs

-74 - 
Round your floral horn of plenty.

Listen, listen: tragic dirges,

Threnodies, death bells, laments!

Listen, listen: happy lieder,

Anthems, hallads, barcaroles!

Give your gifts to every being -.

Every soul is nature's child.

Give your nectar to all creatures -.

Small and large and dark and white.

Sin disturbs the cosmic order

And sends down blight to your fair cheeks.

Make your protean forms phases

Toward a glorious full moon.

Listen, listen: dark leaf-cutters,

Honeybees and bumblebees.

Long-horned bees and slaving workers,

Carpenters and mining bees,

Pindar's feeders, moonlight creatures,

And a swarm of dreary drones.

Listen, listen; look around you:

Galaxies of butterflies --

Monarchs, orange tips and skippers,

Fritillaries, tortoiseshells,

Painted ladies, peacocks, graylings,

Marbled whites and chalk hill blues,

Morphos, emperors and sulphurs,

Admirals and swallowtails.

Give your nectar to all creatures

Give your gifts to every tribe!

\section{CHORUS}


Listen, listen, Golden City:

What a pity,

If my witty

And wise words are soon forgotten!

Misbegotten

Mooncalfs howling,

Nightly prowling

On the Vaal and Drakensberg.

Listen, listen, Treeless Kingdom -.

Undulating veld and hills:

Love begets the noblest freedom

And the nearing tempest stills.

Listen, listen, Table Mountain:

Your southeasters -- wailing beasts --

Are about to raze the fountain

Of abundance, bliss, and feasts.

Give your gifts and they'll return,

For to share is but to earn!

Listen, listen, Sugar Queen:

Let the rickshaw pullers prance --

In bright raiment, tall and lean -.

Let ngoma youngsters dance

By your sea, your sapphire sea.

Let them see

That you treasure

Knows no measure -

Treasure hidden in your heart.

Listen, listen, Garden City.

Listen, listen, Serpent City.

Listen, listen, Diamond City

Listen, Magic Land of dreams,

Stellar dreams!

Torches burn you, fireflies blind you.

So, with candles, leave behind you

-76 - 
Gloom and darkness,

Deadly darkness!

II. The Maker of Helen's Phantom

Brilliant bracts and dazzling petals,

Thrilling phases, priceless gifts

From the Floater, Sailor, Swimmer,

From the Old Man of the Sea.

Like the pliant Taliessin --

Fairest-horned with Moses rays --

Neptune's son enjoys the ocean's

Changing moods and shifting winds.

King of Pharos and First Prophet,

Sleeping with a flock of seals,

Tending herds of grim sea-monsters,

He can see the distant past

And foretell the misty future.

By the mouth of Egypt's Nile.

Rising from the tears of Isis,

He assumes a thousand forms

Lion, leopard, tiger, dragon,

Boar and water, fire and tree.

But if mortal holds the ancient

Sea-god fast, he'll soon possess

Boundless knowledge, lore, and wisdom -.

Tuil and labour lead to light.

And when knowledge of the present,

Of the future and the past

Reigns supreme, then man's endeavours,

Stage by stage, will bring a world

Radiating Love and Justice.

Truth and Beauty, Joy and Peace!

\section{CHORUS}

$-77-$ 
Fairest Queen,

Evergreen

And serene,

Every bract,

Now attacked

By the drones,

Will attract

Liberated mining bees

And free-flying long-horned bees

That will sit on gleaming thrones.

And the song of the drone --

The bagpipe's monotone

And the buzzing of yore --

Will be heard nevermore.

\section{Every bright \\ Butterfly}

Will soon fly,

In your fretful foes' twilight --

Every morarch, marbled white,

Skipper, sulphur, swallowtail,

Dark and white, female and male -.

Here to dance and sip your ale.

Listen, listen, Sugar Bush:

Never let your old flaws push

Your kind heart to black despair.

Once you dare

Gifts to share.

You become a cornucopia

And vreate a new utopia.

Listen, Cities, famed, renowned:

Stride through stages

Taught by sages,

And you'll be with glory crowned.

King of Pharos, wisely fickle,

-78 - 
Never touched by C.ronus' sickle,

Change the trickle

To a river. Ocean towers,

Snow-white flowers,

Rainbow-showers,

Neptune's horses,

Change to forces

That will slowly build a bridge,

Bond of Love from ridge to ridge.

Helen's phantom, who had been

Wafted to the Nile unseen,

Once again became a fair

Reigning queen with golden hair,

Flaming like galactic fire.

So will soon a ghost expire,

And a happy, joyful throng

Will be singing a new song:

"White is Black and Black is White,

And your burden is my plight.

When true Love becomes life's leaven,

Life on earth is life in heaven!" 